Revue d'histoire de l'Amérique française

REYUE D.HISTOIRE DE L'AMÉRIQUE FRANÇAISE

\title{
Dossier sur un centenaire 1848-1948
}

Rétablissement de la langue française dans ses droits officiels

\section{Lionel Groulx}

Volume 2, numéro 1, juin 1948

URI : https://id.erudit.org/iderudit/801431ar

DOI : https://doi.org/10.7202/801431ar

Aller au sommaire du numéro

Éditeur(s)

Institut d'histoire de l'Amérique française

ISSN

0035-2357 (imprimé)

1492-1383 (numérique)

Découvrir la revue

Citer ce document

Groulx, L. (1948). Dossier sur un centenaire 1848-1948 : rétablissement de la langue française dans ses droits officiels. Revue d'histoire de l'Amérique française, 2(1), 97-112. https://doi.org/10.7202/801431ar d'utilisation que vous pouvez consulter en ligne.

https://apropos.erudit.org/fr/usagers/politique-dutilisation/ 


\section{DOSSIER}

sur un centenaire 1848-1948

\section{RÉTABLISSEMENT DE LA LANGUE FRANCAISE DANS SES DROITS OFFICIELS}

\section{Pièce No 1}

ART. XLI DE LA CONSTitution DE 1840. - Kennedy, W.P.M., Statutes, Treaties and Documents of the Canadian Constitution 1713-1929, Oxford University Press 1930, p. 439-40.

XLI. And be it enacted that from and after the said reunion of the said two Provinces, all writs, proclamations, instruments for summoning and calling together the Legislative Council and Legislative Assembly of the Province of Canada and for proroguing and dissolving the same, and all writs of summons and election, and all writs and public instruments whatsoever relating to the said Legislative Council and Legislative Assembly or either of them, and all returns to such writs and instruments, and all journals, entries, and written or printed proceedings of what nature soever of the said Legislative Council and Legislative Assembly and each of them respectively, and all written or printed proceedings and reports of committees of the said Legislative Council and Legislative Assembly respectively, shall be in the English language only: Provided always, that this enactment shall not be construed to prevent translated copies of any such documents being made, but no such copy shall be kept among the records of the Legislative Council or Legislative Assembly, or be deemed in any case to have the force of an original record.

\section{Pièce No 2}

IMPRESSION DES JOURNAUX DE L'ASSEMBLÉE LÉGISLATIVE DE LA YROVINCE DU CaNADA DANS les deUX langues. Et ce, dès la première session de 1841. - Journaux de l'Assemblée législative de la Province du Canada du 14e juin au 18e septembre, 1841. Dans les 4e. et 5e. années de notre Souveraine, LA REINE VICTORIA. Première session du parlement provincial du Canada. Session 1841. Imprimés par Desbarats \& Cary, 1842. p. 303. 
$R E ́ S O L U$, Que les Impressions Journalières de cette Chambre, et l'Impression des Journaux et de l'Appendice de la présente Session, soient données à Messieurs Desbarats et Cary, qui ont offert de faire l'ouvrage aux prix suivants, savoir:

Impressions journalières dans la langue Anglaise, 2s. 6d. par 1000 Ems. Do. dans la langue Française, 2s.9d. par 1000 Ems. Journaux et Appendices, dans les langues Anglaise et Française, 2s.3d. par 1000 Ems.

Piece No 3

TRADUCTION DES LOIS EN LANGUe FRANCAISE. - Journaux de l'Assemblée législative de la Province du Canada du 14e juin au 18e septembre 1841. Dans les $4 e$, et 5e. années de notre Souveraine, LA REINE VICTORIA. Première session du parlement provincial du Canada. Session 1841. Imprimés par Desbarats \& Cary, 1842, p. 490.

Ordonné, Que M. Parent ait la permission d'introduire un Bill pour pourvoir à ce que les Lois de cette Province soient traduites dans la langue Française, et pour d'autres objets y mentionnés.

Il a en conséquence présenté le dit Bill à la Chambre, lequel a óté reçu, et lu pour la première fois.

Ordonné, Que le dit Bill soit lu une seconde fois Lundi prochain .

Ibidem, p. 517.

Conformément à l'Ordre, un Bill pour pourvoir à ce que les Lois de cette Province soient traduites dans la langue Française, et pour d'autres objets y mentionnés, a été lu une seconde fois.

Ordonné, Que le dit Bill soit grossoyé.

Ibidem, p. 521 .

Un Bill grossoyé pour pourvoir à ce que les Lois de cette Provinco soient traduites dans la langue Française, et pour d'autres objets $\mathbf{J}$ mentionnés, a été lu pour la troisième fois.

Résolu, Que le Bill passe, et que le titre soit « Acte pour pourvoir " à ce que les Lois de cette Province soient traduites dans la Langue (Française, et pour d'autres objets y relatifs. ")

Ordonné, Que M. Parent porte le dit Bill au Conseil Législatif, et demande son concours.

\section{Pièce No 4}

Le 6 septembre 1842 les conseillers du district de Terrebonne, dans une requête aux deux Chambres du Canada, prient La Fontaine:

1) d'amender l'Acte d'Union en réhabilitant la langue Française dan. les procédés parlementaires. (AC. vol. IV des Papiers LaFontaine) 
Pièce No 5

discours de lafontaine, 13 septembre 1842. (Extrait): GrodLx, Lionel, Vers l'indépendance politique - Un centenaire de liberté, Ed. l'Action Nationale, Montréal 1942, p. 26.

On me demande de prononcer dans une autre langue que ma langue maternelle le premier discours que j'aie à faire dans cette Chambre. Je me défie de mes forces à parler la langue anglaise. Mais je dois informer les honorables membres que, quand même la connaissance de la langue anglaise Ine serait aussi familière que celle de la langue française, je n'en ferais pas moins mon premier discours dans la langue de mes compatriotes canadiensfrançais, ne fût-ce que pour protester solennellement contre cette cruelle injustice de l'Acte d'Union qui tend à proscrire la langue maternelle d'une moitié de la population du Canada. Je le dois à mes compatriotes, je le dois à moi-même.

Pièce No 6

Pfetition de lafontaine (9 décembre 1844): Journaux de l'Assemblée Législative de la Province du Canada, depuis le 28ème jour de Novembre, 1844, jusqu'au 29ème jour de mars, 1845. Les deux jours inclus, et dans la huitième année du règne de notre souveraine Dame la Reine Victoria - Étant la première session du second parlement provincial du Canada, Session, 1844-5. Imprimés par Ordre de l'Assemblée Législative. p. 29.

Sur motion de l'Honorable M. La Fontaine, secondé par M. Christie.

Résolu, Qu'il soit présenté une humble Adresse à Son Excellence le Gouverneur Général, priant Son Excellence de vouloir bien faire mettre devant cette Chambre, copie de toute correspondance entre le Gouvernement Exécutif de cette Province et le Gouvernement Impérial, depuis la passation de l'Acte d'Union jusqu'à ce jour, relative à la quarante-et-unième section du dit Acte d'Union, par laquelle il est statué que certains Writs, Proclamations, Instrumens, Journaux, Entrées et Procédés écrits ou imprimés et Rapports tels que spécifiés dans la dite section ne seront qu'en langue Anglaise seulement.

Ordonné, Que la dite Adresse soit présentée à son Excellence le Gouverneur Général, par tels Membres de cette Chambre qui forment partie de l'Honorable Conseil Exécutif de cette Province.

\section{Pièce No 7}

Regolution de l'honorable D.-B. PAPINEAU.

Ibidem (20 décembre 1844), p. 92-93.

Qu'il soit présenté une humble Adresse à Sa Majesté renouvelant l'expression des sentimens affectueux de cette Chambre pour la personne et le Gouvernement de Sa Majesté. 
Exposant que, sachant apprécier les avantages que nous retirons de la sollicitude et de la protection de Sa Majesté, et dont cette chambre espère que nous pourrons jouir longtems sous l'autorité paternelle de Sa Majesté, il sera toujours du devoir de cette Chambre de soumettre à la trés gracieuse considération de Sa Majesté les matières qui peuvent avoir, auprès d'aucune classe des sujets de Sa Majesté, la tendance à diminuer le contentement que Sa Majesté désire, cette Chambre en a l'assurance, voir régner dans toutes les parties de ses domaines.

Représentant que le Français est la langue maternelle d'une classe très nombreuse des sujets de Sa Majesté en cette Province. Que de fait la grande masse de ceux qui composent cette classe ne parlent pas d'autre langue. Que c'est dans cette langue que la plus grande partie de leurs lois et leurs livres de Jurisprudence sont écrits, et que se traitent les affaires journalières qu'ils transigent entre eux.

Que c'est la seule langue dans laquelle ils puissent invoquer les bénédictions du ciel sur eux et sur tout ce qui leur est cher. Qu'une langue aussi indispensable à une aussi forte portion du peuple fidèle de Sa Majesté, ne peut, dans l'opinion de cette Chambre être regardée comme une langue étrangère par leur Souverain, lorsqu'ils s'en servent.

Rappelant que les prédécesseurs royaux de Sa Majesté placèrent sur le même pied les langues des deux grandes classes des sujets de Sa Majesté en cette Province, les traitant tous à cet égard avec une égale justice et leur donnant le même avantage.

Faisant remarquer que ce principe fut constamment maintenu jusqu'à la passation de l'Acte qui unit ces Provinces. Que cette Chambre ne met pas en doute que les meilleurs intentions et les meilleurs motifs n'aient animé ceux qui décrétèrent la disposition par laquelle il fut déclaré:

"Que tous les Writs, proclamations, instrumens pour sommer et " convoquer le Conseil Législatif et l'Assemblée Législative de la ( Province du Canada, et pour icelle proroger et dissoudre; et tous ( Writs et instrumens publics quelconques se rapportant aux dits "Conseil Législatif et Assemblée Législative, ou l'un ou l'autre, " et tous rapports sur tels Writs et instrumens, et tous journaux, " entrées et procédés écrits ou imprimés, de nature quelconque " des dits Conseil Législatif et Assemblée Législative, et de chacun " d'eux respectivement, et tous procédés, écrits ou imprimés, et " rapports de Comités des dits Conseils Législatif et Assemblée ( Législative respectivement, seront dans la langue Anglaise ( seulement ).

Disant que dans la première Session même de la Législature, sous l'opération de l'Acte ci-dessus, il devint indispensable de traduire en français tous les documens et pièces publics. Et à moins de réduire au silence une partie des Représentans du peuple, les débats n'eurent ni 
ne pourraient avoir lieu sans l'usage de cette langue. Que dans les Cours de Justice èt les procédés judiciaires, elle s'est trouvée d'une égale nécessité après comme avant l'union, et dans tous les rapports ordinaires de la vie, elle est d'un usage aussi étendu que jamais.

Remontrant que la seule distinction qui existe, c'est que la langue Française ne peut être la langue légale des actes parlementaires, distinction de peu d'importance peut-être en elle-même, de nature à produire aucun résultat avantageux dans les sentimens ni les habitudes de ceux qui la parlent, mais provoquant chez eux un sentiment défavorable à la paix et à la tranquilité de la Province, en autant que cette proscription limitée de leur langue semble comporter, quoique sans intention, l'imputation d'une distinction défavorable à leur égard.

Représentant que cette Chambre, mue par le désir d'unir tous les cœurs en cette Province, dans une même affection pour la personne de Sa Majesté, et dans un même appui de son Gouvernement, prie humblement Sa Majesté de faire disparaître cette cause de mécontentement, et de recommander au Parlement Impérial de révoquer la partie de la loi qui lui a donné naissance, assurant Sa Majesté que cette démarche sera accueillie par le peuple loyal Canadien de Sa Majesté, comme une nouvelle marque de sa sollicitude paternelle pour son bien-être.

Ordonné, Que la considération ultérieure de la dite motion soit remise à Samedi le onzième de Janvier prochain.

Ordonné, Que cinq cens exemplaires de la dite motion soient imprimés dans chacune des langues Anglaise et Française, pour l'usage des Membres de cette Chambre.

Cette " motion ) fut prise en considération le 31 janvier 1845 et ce jour-là même ("adoptée unanimement) par la Chambre. La Chambre nomma tout aussitôt un Comité spécial composé de l'Honorable M. Papineau, l'Honorable Procurenur Général Smith, l'Honorable M. Moffat, l'Honorable $M$. LaFontaine et l'Honorable M. Morin pour "préparer et rapporter le Projet d'une humble Adresse à Sa Majesté 》.

Ibidem (13 fév. 1845, 227-29.)

\section{Piece No 8}

Ibidem (21 février 1845) p. 294-95.

L'Honorable M. Papineau, du Comité spécial nommé pour préparer et rapporter le projet d'une Adresse à Sa Majesté, au sujet de la Langue Française, en conformité d'une résolution adoptée par la Chambre, le trente-et-un Janvier, 1845, a présenté à la Chambre l'Adresse préparée par le dit Comité, laquelle Adresse a été lue de 
nouveau à la table du Greffier, et adoptée parla Chambre; et elle e oomme suit: -

\section{A la Très Excellente Majesté de la Reine \\ TRÈS GRACIEUSE SOUVERAINE,}

Nous, les fidèles et loyaux sujets de Votre Majesté, les Communes du Canada, assemblées en Parlement Provincial, prenons respectueusoment la liberté de renouveler auprès de Votre Majesté, l'expression de notre dévouement à la personne et au Gouvernement de Votre Majeste, et d'exposer: -

Que sachant apprécier les avantages que nous retirons de la sollicitude et de la protection de Votre Majesté, et dont cette Chambre espère que nous pourons jouir longtems sous l'autorité paternelle de Votre Majesté, il sera toujours du devoir de cette Chambre de soumettre à la très gracieuse considération de Votre Majesté, les matières qui peuvent avoir auprès d'aucune classe de sujets de Votre Majesté, la tendance de diminuer le contentement que Votre Majesté désire, cette Chambre en a l'assurence, voir régner dans toutes les parties de ses domaines.

Que le Français est la langue maternelle d'une classe très nombreuse des sujets de Votre Majesté, en cette Province; Que de fait, la grande masse de ceux qui composent cette classe ne parlent pas d'autre langue: Que c'est dans cette langue que la plus grande partie de leurs lois et leurs livres de jurisprudence sont écrits, et que se traitent les affaires journalières qu'ils transigent entre eux; Que c'est la seule langue dans laquelle ils puissent invoquer les bénédictions du ciel sur eux et sur tout ce qui leur est cher; Qu'une langue aussi indispensable à une aussi forte portion du peuple fidèle de Votre Majesté, ne peut, dans notre opinion, être regardée comme une langue étrangère par leur Souveraine, lorsqu'ils s'en servent.

Que les prédécesseurs Royaux de Votre Majesté placèrent sur le même pied les langues des deux grandes classes des sujets de Votre Majesté eu cette Province, les traitant tous à cet égard avec une égale justice et leur donnant le même avantage.

Que ce principe fut constamment maintenu jusqu'à la passation de l'Acte qui unit ces Provinces.

Que cette Chambre ne met pas en doute que les meilleurs intentions et les meilleurs motifs n'aient animé ceux qui décrétèrent la disposition par laquelle il fut déclaré:

(Que tout les writs, proclamations, instrumens pour sommer et convoquer le Conseil Législatif et l'Assemblée Législative de la Province du Canada, et pour les proroger et dissoudre, et tous writs de sommation et d'élection, et tous writs et instrumens publics quelconques se rapportant aux dits Conseil Législatif et Assemblée Législative, 
ou l'un ou l'autre, et tous rapports sur tels writs et instrumens, et tous journaux, entrées et procédés écrits ou imprimés, de nature quelconque, des dits Conseil Législatif et Assemblée Législative et de chacun d'eux respectivement, et tous procédés, écrits ou imprimés, et rapport de Comités des dits Conseil Législatif et Assemblée Législative respectivement. seront dans la langue anglaise seulement. ")

Mais que dans la première Session même de la Législature sous l'opération de l'Acte ci-dessus, il devint indispensable de traduire en français tous documens et pièces publics. Et à moins de réduire au silence une partie des Représentans du peuple, les débats n'eurent et ne pouvaient avoir lieu sans l'usage de cette langue; Que dans les Cours de Justice et les procédés judiciaires elle s'est trouvée d'une égale nécessité après comme avant l'Union, et que dans tous les rapports ordinaires de la vie elle est d'un usage aussi étendu que jamais.

Que la seule distinction qui existe, c'est que la langue Française ne peut être la langue légale des Actes Parlementaires, - distinction de peu d'importance peut-être en elle-même, de nature à ne produire aucun résultat avantageux dans les sentimens ni les habitudes de ceux qui la parlent, - mais provoquant chez eux un sentiment défavorable à la paix et à la tranquillité de la Province, en autant que cette proscription limitée de leur langue semble comporter, quoique sans intention, l'imputation d'une distinction défavorable à leur égard.

Que mus par le désir d'unir tous les cœurs, en cette Province, dans une même affection pour la personne de Votre Majesté, et dans un même appui de son Gouvernement, nous prions humblement Votre Majesté de faire disparaître cette cause de mécontentement, et de recommander au Parlement Impérial de révoquer la partie de la loi qui lui a donné naissance, assurant Votre Majesté que cette démarche sera accueillie par le peuple Canadien de Votre Majesté, comme une nouvelle marque de la sollicitude paternelle de Votre Majesté pour son bien-être.

Ordonné, Que la dite Adresse soit grossoyée.

Résolu, Que la dite Adresse soit communiquée, par Message à l'Honorable Conseil Législatif, demandant le concours de leurs Honneurs à icelle.

Ordonné, Que l'Honorable M. Papineau, porte le dit Message au Conseil Législatif.

Piece No 9

Le 19 mai 1845, lord Stanley, dans une dépêche " private and confidential ), répondit à Metcalfe au sujet de cette (" Adresse " des deux Chambres. Saura-t-on jamais le contenu de cette dépêche de Stanley? Qu'est-il advenu de ce document politique? La pièce que nous publions ci-après nous fournit quelques renseignements. Meticalfe paraît avoir montré la réponse 
de Stanley aux membres du Conseil exécutif d'alors et en particulier aux ministres canadiens-français; il invoqua toutefois le caractère privé et confidentiel du document pour refuser de le déposer officiellement devant le ministère. On peut conjecturer néanmoins que Stanley ne se montra guère favorable à la pétition du Parlement Canadien. En 1848 lorsque l'abrogation de l'art. LXI vint devant la Chambre des lords, Stanley fut seul à s'y opposer. La reconnaissance officielle de la langue française au Canada dresserait d'après lui " une barrière permanente entre les deux parties du pays "). (KenNedY, op. cit., p. 533 note $1 \mathrm{e}$ ).

Aux Archives du Canada nulle trace n'est restée de la réponse de Stanley. En existerait-il une copie à Londres? Il ne semble point. En 1928, j'étudiais cette période. N'ayant pu mettre la main sur la pièce précieuse, je m'en ouvris à l'archiviste d'alors, M. Arthur G. Doughty. Celui-ci, dans l'espoir de m'être utile, voulut bien câbler immédiatement à Londres. Voici la réponse qui me fut communiquée:

\section{PUBLIC ARCHIVES OF CANADA}

Dear Abbé Groulx:-

Ottawa, 3 January 1928.

I enclose for your information a copy of the reply Dr. Doughty has received from England in response to his cable of enquiry regarding Lord Stanley's letter of May 19, 1845 to Sir Charles Metcalfe.

Abbé Lionel Groulx Yours very truly, 3716 Saint-Hubert St., Montreal, Que.

\section{PUBLIC ARCHIVES OF CANADA}

\section{(Copy)}

\section{Public Record Office} Chancery Lane

Dear Doughty: London, W.C.2. 21 December, 1927.

With further reference to my letter of December 16, I have today had a reply from the Librarian at Knowsley to say he can find no trace of any correspondence from Lord Stanley to Sir Charles Metcalfe. I much fear therefore that there is no chance of discovering the letter of May 19, 1845 , but shall still bear it in mind.
Dr. A.G. Doughty C.M.G., Public Archives, Ottawa, Ont.
(Signed) H.P. Biggar

Yours truly,

[Pour copies conformes $=$ Lionel Grovlx, ptre $]$ 
Pièce No 10

\author{
(Cathcart à Lord Stanley)
}

My Lord,

Montreal 19th Decr. 1845.

I conceive it to be my Duty to intimate to Your Lordship that a Member of the Executive Council of this Province has applied to me to lay before thatBody Your Lordship's Communication marked Private of the 19th May last, to Lord Metcalfe, relating to the Address of Last Session from the local Legislature to the Crown, praying for the repeal of that Clause in the Act of Reunion of Upper \& Lower Canada which enjoins the exclusive use of the English Language in the Legislative Records of the Provincial Parliament

It would seem that Lord Metcalfe considered it right to communicate privately to the Exiecutive Council the Sentiments entertained by your Lordship upon this important, and to the French Canadian Councillors especially, interesting subject, but that Lord Metcalfe did not officially lay before the Council your Lordship's Letter it being of a private \& Confidential Character; for the same reason, I have declined to comply with the request that has been proferred.

It is not probable that Your Lordship will overlook this question; but it appears to me to be proper to inform you that the Executive Council are of opinion that it would be very desirable if the Gov. Genl. were authorized by your Lordship to communicate on the opening of the approaching Session of the Provincial Parliament, a favorable reply to the Address and I therefore venture to solicit your Lordship's early consideration of the subject.

$$
\begin{gathered}
\text { I have etc } \\
\text { Carthcart }
\end{gathered}
$$

AC. G. 460 , p. 512-13.

Pièce No 11

(W.E. Gladstone à Earl Cathcart)

Downing Street

3 February 1846.

My Lord,

I have laid before the Queen the joint Address of the Legislative Council and Assembly of Canada on the subject of the alteration of the Act of the Re-union of Canada so far as respects the use of the French Language.

I have also laid before The Queen your Despatch of the 8th. of March 1845 N. 287 which transmits the above address. 
From regard to the wishes thus expressed by Her loyal Subjects, Her Majesty is inclined to entertain the prayer of that Address, and authorises you to make a communication accordingly to the Legislative Bodies at the opening of the Session.

Inasmuch however as it would not be practicable to obtain from Parliament with convenience the change which is required in the Act of Re-Union so early as to take effect upon the proceedings of the coming Session in Canada, and as it is obviously far from desirable that reiterated applications should be made for the alteration of a Constitutional Statute of so much importance, Her Majesty's Government do not propose to take any step of that nature until I shall have become acquainted with the proceedings of the Provincial Legislature, and shall have learned whether they may give occasion for inserting in one and the same amending Bill, together with a provision relating to the exclusive use of the English language, another modification of the provisions of the Act. of Reunion which might possibly become necessary under the powers conveyed to your Lordship in my Despatch of this date relating to the Civil List.

I have etc.

(signed) W.E. Gladstone

AC. G. 449 , no 20 .

Pièce No 12

Earl Grey

Montreal 2 March 1848

My Lord,

I beg leave to refer to the Correspondence noted in the Margin respecting the Joint Address of the Legislative Council and Assembly of this Province praying for the repeal of the 41 Clauses of the Act. of Union relating to the French Language.

Mr. Gladstone in conveying to the two Houses Her Majesty's Answer to this Address, stated that Her Majesty's Government would take no steps for procuring the requisite Amendment in the Union Act until they should be apprised of the further alterations that would be required in it by the proceedings which it was anticipated would take place in the Canadian Legislature on the subject of the Civil List, in order that both Measures might be included in one and the same amending Bill. The Imperial Parliement has since, on the Solicitation of the Legislature, passed an act relating to the Civil list, while the pledge given by H. M. Govt, on the subject of the French Language appears to have been overlooked. Under these circumstances I think the subject under your notice, as it is one on which a very strong and general feeling exists here.

I have etc.

AC. G. 461, p. 188 .

Elgin \& Kincardine. 
Pièce No 19

Collection Elgin-Gney 1846-1852, éditée avec notes et appendices par Sir Arthur G. Doughty, C.E.B., en 4 tomes.

(Extrait de: vol. 1, p. 149-150).

(Elgin à Grey, Montreal - May 4. 1848).

I am very anxious to hear that you have taken steps for the repeal of so much of the Act of Union as imposes restrictions on the use of the French language. The delay which has taken place in giving effect to the promise made, I think by Gladstone, on this subject, is one of the points of which M. Papineau is availing himself for purposes of agitation. I must moreover confess that I for one am deeply convinced of the impolicy of all such attempts to denationalize the French. Generally speaking they produce the opposite effect from that intended, causing the flame of national prejudice and animosity to burn more fiercely - But suppose them to be successful what $\mathrm{w}^{\mathrm{d}}$ be the result? You may perhaps americanise, but, depend upon it, by methods of this description, you will never anglicise the French inhabitants of the Province. - Let them feel on the other hand that their religion, their habits, their prepossessions, their prejudices if you will, are more considered and respected here than in other portions of this vast continent which is being overrun by the most reckless, selfsufficient and dictatorial section of the Anglo Saxon race, and who will venture to say that the last hand which waves the British flag on American ground may not be that of a French Canadian?

Ibidem, p. 164-65. (Grey à Elgin, Belgrave Square, June 1,48)

I quite agree with you as to the impolicy of the attempt to civilize the French Canadians by measures wh. are obnoxious to them, \& therefore tho' I confess I am sorry to alter the Union Act as regards the language I shall almost immediately yield to their wishes by bringing in a Bill to affect the desired change. You will receive an official announcement of this intention by this mail.

Ibidem, p. 180. (Elgin \& Kincardine à Grey, Montreal June 1, 1848)

Let me also remind you of the importance which attaches to the passing of a measure to remove the restrictions imposed by the Act of Union on the use of the French language.

Ibidem, p. 183. (Elgin \& Kincardine à Grey, Montreal. June 15,1848) I trust that the next Bag from Downing Street will inform me what you intend to do in order to repeal the restrictions on the use of the French Language imposed by the Union Act. I am very anxious on this point. La Fontaine is constantly speaking to me about it - I believe these provisions to be most impolitic - \& calculated to produce the very opposite effects from those intended. Their repeal has been 
applied for in an address, I believe, unanimously voted, by the local legislature and promised by the Secretary of State. Why should it be delayed?

[Grey donna sa réponse dans une dépêche du 27 mai1848. A prèsavoir noté que l'art. LXI n'était pas venu en discussion lorsque l'amendement au sujet de la liste civile avait été soumis au Parlement anglais, Grey. continuait]:

I was induced to hope that a further experience of the existing Law might have led to the conclusion that it might be allowed to continue unaltered without any serious inconvenience; and as I cannot disguise from your Lordship that it is not entirely without reluctance that Her Majesty's present Advisers will propose the desired alteration in the Re-Union Act, I willingly availed myself of the silence of your Lordship and of the Provincial Legislature, to omit doing so when the amendment of the Act with respect to the Civil List was brought before Parliament. (Grey to Elgin, No 217 AC. G. 131, p. 128).

Collection Elgin-Grey, vol. I p. 201. (Grey à Elgin, C.O. July 14,48)

I shall only write You a single line this week - The Bill for the amendment of the Union Act was read a 2nd time last night in the Lords \& will soon I trust pass into a Law. In moving it I made a short statement of my opinion as to the policy of allowing Canada to Govern herself \& as to the success with wh. you have acted upon it, showing how loyal the people in consequence are \& reading the address from London (Canada West) \& the presentment of the Montreal Grand Jury. I thought that this might be of some use $\mathrm{t}[\mathrm{o}]$ you, but I might have saved myself the trouble, for as usual when there is no party contest involved in the question the $\mathrm{H}$. of Lords $\mathrm{w}^{\mathrm{d}}$ not pay the slightest attention $t[0]$ a Colonial subject, \& also as usual the Reporters did not think it worth while reporting what passed.

Ibidem, p. 287. (Elgin \& Kincardine à Grey, Montreal Jany 18. 1849)

I have just returned from the House of Part where I have opened the Session in a speech of which I trust you will approve - Taking advantage of the repeal of the Law restricting the use of the French Language I delivered my Speech in both Languages - I know nothing of the effect of the Speech yet but I may hear something before this letter departs as I go to town tonight to.attend the theatre.

Ibidem, p. 288. (Grey à Elgin, C.O. Feby 9,49).

I have only one moment today to answer your letter of the $18^{\mathrm{t}}$ of Jany \& to say that I think your speech an excellent one \& your delivering it in French as well as in English a very good move, you have opened your Session I think most prosperously. 
Pièce No 14

ABrogation De L'ARTICle LXI - Statutes, Treaties and Documents of the Canadian Constitution 1713-1929. Edited by W.P.M. Kennedy,

and Vict., .35 . Second edition. Oxford University Press, 1930, p. 532-33.

THE UNION ACT AMENDMENT ACT, 1848

(11 \& 12 Victoria, c. 56)

An Act to repeal so much of an Act of the Third and Fourth Years of her present Majesty, to re-unite the Provinces of Upper and Lower Canada, as relates to the use of the English Language in Instruments relating to the Legislative Council and Legislative Assembly of the Province of Canada.

14th August, 1848.

Whereas by an Act passed in the session of Parliament held in the third and fourth years of Her Present Majesty, intituled " An Act to reunite the Provinces of Upper and Lower Canada, and for the Government of Canada "), it is amongst other things enacted that from and after the said reunion of the said two Provinces, all writs, proclamations, instruments for summoning and calling together the Legislative Council and Legislative Assembly of the Province of Canada, and for proroguing and dissolving the same, and all writs of summons and elections, and all writs and public instruments whatsoever relating to the said Legislative Council and Legislative Assembly, or either of them, and all returns to such writs and instruments, and all journals, entries, and written or printed proceedings, of what nature soever, of the said Legislative Council and Legislative Assembly, and of each of them respectively, and all written or printed proceedings and reports of Committees of the said Legislative Council and Legislative Assembly respectively, shall be in the English language only: Provided always that the said enactment shall not be construed to prevent translated copies of any such documents being made, but no such copy should be kept among the records of the Legislative Council or Legislative Assembly, or be deemed in any case to have the force of an original record: And whereas it is expedient to alter the law in this respect, in order that the Legislature of the Province of Canada, or the said Legislative Council and Legislative Assembly respectively, may have power to make such regulations herein as to them may seem advisable: Be it therefore enacted oy the Queen's most excellent Majesty, by and with the advice and consent of the Lords Spiritual and Temporal, and Commons, in this present Parliament assembled, and by the authority of the same, that from and after the passing of this Act so much of the said recited Act as in hereinbefore recited shall be repealed.

II. And be it enacted that this Act, or any part thereof, may be repealed, altered, or varied at any time during the present session of Parliament. 
Pièce No 15

mxtrait du discours de la couronne prononcé à l'ouverture du Parlement de la Province du Canada - 18 janvier 1849.

Lord Elgin:

" Je suis fort aise d'avoir à vous apprendre que, conformément au désir de la Législature locale, exprimé dans une Adresse des deux Chambres du Parlement provincial, le Parlement impérial a passé un acte révoquant la clause de l'Acte d'Union qui imposait des restrictions à l'usage de La langue Française ").

(Extrait de: Journaux de l'Assemblée législative de la Province du Canada - Session 1849 - Vol. VIII, part. 1ère. Montréal, Becket, p. 13).

Pièce No 16

IMPRESSIONS DIVERSES $r$ ABROGATION DE L'ARTICLE LXI.

Colonel Prince (Député d'Essex):

Cette réapparition de la langue française lui paraît « tout à fait ridicule ". Elle résonnait de façon singulièrement désagréable " aux oreilles de tout Anglais pur sang ". Et puisqu'il y avait au Canada des Écossais et des Allemands, le député d'Éssex espérait que l'année suivante " on lirait sans doute le discours [de la couronne] en allemand et en broad scotch "... (Extrait de: La Minerve, 25 et 29 janvier 1849).

\section{L.-J. Papineau:}

" Je me lève, dit M. Papineau, pour dire le peu de mots que j'ai à dire à l'occasion des circonstances qui ont accompagné la convocation du parlement provincial, cette année. Dans la manière qu'il a été ouvert, il y a quelque chose d'inaccoutumé. C'est un acte de justice par trop agréable, trop digne d'approbation, de la part du souverain du pays, pour qu'on pût se permettre d'en faire un sujet de basses railleries, comme on s'en est permises. Le gouverneur a prononcé son discours en français et en anglais. Le rétablissement de la langue française dans le parlement canadien était un acte de stricte justice, que nous devait l'autorité constituée. Son Excellence remplissait donc son devoir en agissant comme il l'a fait. Il l'a fait avec toute l'attention et la courtoisie qu'on devait en justice au peuple de cette province, et on doit lui en savoir gré. L'année dernière, j'ai été blessé, j'ai été profondément affligé dans l'occasion solennelle où le parlement a été convoqué de voir que le discours du trône n'eût pas été prononcé en langue française. Dans les usages du pays, cette pratique avait toujours eu lieu. Il est vrai que les gouverneurs, n'ayant pas toujours l'éducation qui semble insé- 
parable de la langue du pays le plus civilisé de l'Europe, étaient souvent obligés de faire lire les discours par un de leurs subrogés; mais toujours était-il lu dans la langue française. Il n'y a que depuis l'Union des deux provinces que cet acte de justice a été interrompu ).

" La personne chargée ordinairement de lire le discours du gouverneur, quand il ne pouvait pas le faire lui-même, était l'Orateur du Conseil; et comme il arrivait souvent que celui-ci ne connaissait pas luimême très bien la langue de ses compatriotes, il martyrisait, la plupart du temps, tellement le discours, qu'on pouvait à peine le comprendre. C'est ainsi que l'Orateur du Conseil faisait dire au gouverneur qu'il désirait armer le plus tôt possible la malice canadienne. Le mot malice canadienne était, comme à dessein, toujours substitué au mot milice canadienne. Le discours, cette année, a été prononcé en français avec dignité et d'une manière propre à faire honneur aux sentiments de celui qui l'a prononcé, et à lui mériter la reconnaissance du pays ).

(Extrait de: Dix Ans au Canada de 1840 à 1850 - Histoire de l'établissement du gouvernement responsable par A. Gérin-Lajoie. Québec 1888, p. 491-92).

\section{Denis-Benjamin Viger:}

«Que je me sens soulagé d'entendre prononcer le discours du trône dans la langue de mes pères ! ’)

(Extrait de: Dix Ans au Canada de 1840 à 1850 - Histoire de l'établissement du gouvernement responsable par A. Gérin-Lajoie, Québec, 1888 , p. 490).

LA Minerve:

" La Lecture de ce discours faite en langue française et avec une excellente prononciation par Son Excellence le Gouverneur-Général, a causé une vive satisfaction.... De la part de lord Elgin, c'est une attention délicate, un hommage à notre nationalité dont nous devons lui savoir gré. Il était impossible de mieux nous annoncer la réhabilitation de la langue française dans l'ordre politique ").

(22 janvier 1849).

The Montreal Herald:

" There are some minor matters contained in His Excellency's speech, which have been, indirectly, commented upon by some of our contemporaries, in a spirit, with which, we confess, we have little sympathy. We mean the repeal of the clause in the Union Act, imposing restrictions on the use of the French language; and the general amnesty in favor of all persons, who are still liable to penal consequences, for offences of a political character arising out of the rebellions of 1837 and 1838. The justice and propriety of these measures appear to us, require 
no defence. Time alone, will relieve the country from the great inconvenience attending the use of two languages in our Legislature; but, until its practical necessity has ceased, neither section of our population can, with justice, claim any exclusive preference for their language. It was evidently the repeal of this clause in the Union Act, which induced His Excellency to resort to the former practice in Lower Canada, and use both languages, in addressing the Parliament from the throne. With regard to the general amnesty for all political offenders, it is, under the circumstances of the country, so clearly an act, not only of mercy towards the individual criminals, but of justice towards their innocent relations and connexions, that, with the antopodal exceptions of Mr. Louis Joseph Papineau and the gallant Colonel Prince we can scarcely believe one man can be found in the country, who would raise his voice against it )).

(The Montreal Herald, Thursday Morning, Jan. 25, 1849, cité dans La Collection Elgin-Grey 1846-1852, éditée avec notes et appendices par Sir Arthur G. Doughty, C.E.B. en 4 tomes. T.1, p. 290).

L. G.

\section{Comment signait LaFontaine ?}

La question n'est pas de savoir s'il eût dâ signer de telle ou telle façon, mais bel et bien d'établir comment il signait. On l'aura observé dans les pages que l'on vient de lire, (celles du " Dossier ") et celles de l'article qui précède le "Dossier ") nous avons constamment écrit le nom de LaFontaine, comme formant un seul mot, e'est-à-dire $L a$ lié au reste, et $F$ ontaine avec un $F^{\prime}$ majuscule. Nous ne l'avons pas fait sans raison, mais après l'examen d'une centaine au moins de signatures du personnage, à travers ses manuscrits. Ces manuscrits, chacun peut les consulter comme nous, aux Archives de la Société historique de Montréal, à la Bibliothèque Municipale de la rue Sherbrooke. On y verra que, à l'encontre de ce qui se produit parfeis dans le style des signatures, celle de LaFontaine n'a jamais varié, au moins à partir de 1837. Toujours le $L a$ fait liaison, par un trait sans interruption avee le $F$ majuscule. LaFontaine signe ainsi à la fin de ses lettres. Il écrit son nom de la même manière, dans le cahier de sa "Généalogie " éerite de sa main (voir en particulier, p. 17 et 18); même chose dans son testament où, en raison de son héritier, le nom LaFontaine revient maintes fois; même chose aussi dans les registres officiels du procureur-général. Bon nombre de ses correspondants, et, par exemple, Falconer, Monk, Robert Baldwin, AugustinNorbert Morin, respectent cette signature et la reproduisent, au cours de leurs lettres, avec une fidélité si étonnante qu'on dirait un facsimilé. Sur le monument du Parc LaFontaine, à Montréal, le nom du personnaģ a été sravé dans le même style. Cela, non plus, n'a été fait sans motifs. On pourra encore lire, si l'on veut, dans Hommages à LaFontaine (vol. de 485 pages, publié par le Comitó du Monument LaFontaine, 